UDC 001.8:001.18:336:656:338.1

DOI: https://doi.org/10.32782/2520-2200/2020-1-43

Hrashchenko Iryna
National Aviation University
Krasnyuk Maxim
Kyiv National Economic University named after Vadym Hetman
Krasniuk Svitlana
Kyiv National University of Technologies and Design

Гращенко І.C. кандидат економічних наук, доцент, Національний авіаційний університет

Краснюк М.Т.

кандидат економічних наук, доцент, Київський національний економічний університет імені Вадима Гетьмана

Краснюк С.O. старший викладач Київського національного університету технологій та дизайну

\title{
ITERATIVE METHODOLOGY OF BANKRUPTCY FORECAST OF LOGISTIC COMPANIES IN EMERGING MARKETS, TAKING INTO ACCOUNT GLOBAL/REGIONAL CRISIS
}

\section{IТЕРАТИВНА МЕТОДИКА ПРОГНОЗУВАННЯ БАНКРУТСТВА ЛОГІСТИЧНИХ КОМПАНІИ НА РИНКАХ, ЩО РОЗВИВАЮТЬСЯ В УМОВАХ ГЛОБАЛЬНОЇ/РЕГІОНАЛЬНОЇ КРИЗИ}

Taking into account the globalized, regional, sectoral and pre-crisis specific of the above mentioned task of FA, it is relevant to critically analyze the main methods (and practice of their use) of financial analysis in order to to develop an complex iterative script methodology of FA for LC on emergent markets in pre-crisis or crisis conditions. Summarizing the comprehensive analysis of existing and used methods of FA for LC, and given the author's practical industry experience, it can be confidently stated that no existing algorithm of FA can not give an adequate forecast of the financial status of $L C$ applicable at all stages of the LC life cycle and all phases of a possible crisis in emerging markets. In this article, the important and urgent task is solved: the development of a step-by-step iterative integrated methodology of financial analysis and forecasting the bankruptcy of a logistics company on emergent markets in pre-crisis and crisis conditions, applicable at all stages of the LC life cycle and all phases of a possible crisis.

Key words: financial analysis, logistic company, crisis, emerging markets, predictive model, machine learning.

Світова економіка зростає найповільнішими темпами з моменту останньої світової фінансової кризи 2008-2009 рр., МВФ пояснює це торгівельними війнами, невизначеністю від Brexit, та іншими геополітичними кризами. Навыть поточна епідемія коронавірусу в Китаї може стати несподіваним пусковим фрактором для початку нової глобальної економічної кризи. Усі перераховані вище тенденції та ризики в першу чергу і безпосередньо впливають на галузь транспортних та логістичних послуг. Зрозуміло, що суб'єкти транспортної та логістичної галузі (логістичні компанії - ЛК) не можуть контролювати вищевказані об'єктивні негативні наслідки регіональних та геополітичних кризових явищ. Також, слід зазначити, що антикризова програма ЛК розробляється на основі діагностики фрінансового стану та загрози банкрутства ЛК, моделювання наслідків. У статті проведений всебічний аналіз існуючих методів фрінансового аналізу (ФА - надалі) ЛК та врахований практичний досвід їх використання в умовах трансформаційної економіки. У статті 
обгрунтовані висновки, що жоден окремий існуючий алгоритм ФА не здатен до адекватного прогнозу фрінансового стану ЛК в кризових макроекономічних умовах. 3 огляду на викладене, авторами розроблена ітеративна сценарна покрокова методика ФА, яка передбачає на кожній ітерації аудиту ЛК наступні опції: порядковий номер етапу аудиту, рекомендований сценарійний підхід до агрегування результатів ФА та їх інтерпретації, вхідна інформація для ФА, запропонований метод/ модель ФА, результати етапу ФА, альтернативні управлінські рішення за підсумками етапу (банкрутство ЛК; офріційна ліквідація ЛК; ефективний продаж ЛК новим власникам; вилучення ліквідних активів та фрормальна продаж/перереєстрація ЛК; вдосконалення та реорганізація ЛК з метою продовження подальшої операційної діяльності без перепрофрілювання). Отримані в статті результати можуть бути використані не тільки логістичними компаніями на ринках, що розвиваються, але й іншими видами бізнесу на стабільних та розвинутих ринках в умовах глобальної/регіональної кризи та в докризових умовах

Ключові слова: фрінансовий аналіз, логістична компанія, криза, ринки, що розвиваються, прогностична модель.

В статье проведен всесторонний анализ существующих методов фринансового анализа (ФА) ЛК и учтен практический опыт их использования в условиях трансформационной экономики. В статье обоснованы выводы, что ни один отдельный существующий алгоритм ФА не способен к адекватному прогнозу финансового состояния ЛК на развивающихся рынках в кризисных макроэкономических условиях. Учитывая изложенное, авторами разработана итеративная сценарная пошаговая методика ФА, которая предусматривает на каждой итерации аудита ЛК следующие опции: порядковый номер этапа аудита, рекомендованный сценарийными подход к агрегирования результатов ФА и их интерпретации, входная информация для ФА, предложенный метод/ модель ФА, результаты этапа ФА, альтернативные управленческие решения по итогам этапа. Полученные в статье результаты могут быть использованы не только логистическими компаниями на развивающихся рынках, но и другими видами бизнеса в кризисных и докризисных условиях даже на стабильных и развитых рынках.

Ключевые слова: финансовый анализ, логистическая компания, кризис, развивающиеся рынки, прогностическая модель.

Statement of the problem. The global economy is growing at its slowest pace since the last global financial crisis, the International Monetary Fund has said. The IMF blamed the slowdown on trade fights, Brexit uncertainty and other geopolitical crises [1].

In contrast to extremely weak world manufacturing and trade, the world services sector (which includes logistics) continues to hold up almost across the globe [2]. But current and future global and regional crises (for example trade wars) are instantaneous, regular and unfavorable across the entire transport industry [3].

Future growth is projected by IMF to pick up to $3.4 \%$ in 2020 , reflecting primarily a projected improvement in economic performance in a number of emerging markets in Latin America, the Middle East, and emerging and developing Europe that are under macroeconomic strain (for example - Ukraine [4; 5]).

About half of this rebound is driven by recoveries or shallower recessions in stressed emerging markets, such as Argentina, Iran, and Turkey, and the rest by recoveries in countries where growth slowed significantly in 2019 relative to 2018, such as Brazil, India, Mexico, Russia, and Saudi Arabia [6].

There is, however, considerable uncertainty surrounding these recoveries, especially in conditions of current escalation in the Persian Gulf.
So, as mentioned above, trade, geopolitical and military tensions, could further disrupt economic activity, and derail an already fragile recovery in the aforementioned economies. This could lead to an abrupt shift in risk sentiment, financial disruptions.

For example, from recent events: the current epidemic of the coronavirus in China may become an unexpected trigger for the onset of the global economic crisis $[7 ; 8]$.

All of the above trends and risks will directly affect the industry of transport and logistics services [9].

It is clear that at the macroeconomic level, the subjects of the transport and logistics industry (logistic companies - LC) cannot control above mantioned factors of the emergence of regional and geopolitical crisis phenomena.

That is why the crisis management (particularly in the transport industry) should provide an adequate and systematic multimodal response to the above-mentioned crisis phenomena, that is, the type and strength of the crisis factor requires a greater or lesser force of the reaction, which is expressed in different volumes and cost vectors (financial, time, human, informational resources), and hence in the respective management influences.

All of the above should be included in the crisis program of a logistics company. The suitable methodology of innovative reorganization of the logistic company (and crisis program generation) 
was already developed by authors through LC reengineering [10].

So, based on detailed analisis of the above mentioned scheme of the developed complex cross-cutting methodology of anti-crisis reengineering of LC, it is clear that the task of financial analysis (FA - further on in this document) and forecasting the bankruptcy of a logistics company is relevant, complex, iterative and dynamic task (especially in emerging markets in pre-crisis conditions).

Thus, taking into account the globalized, regional, sectoral and pre-crisis specific of the above mentioned task of FA, it is relevant to critically analyze the main methods (and practice of their use) of financial analysis in order to develop the complex iterative script methodology of FA for LC on emergent markets in pre-crisis or crisis conditions.

Setting objectives. As outlined above companies (including LC) from emerging markets in Latin America, the Middle East, and emerging and developing Europe, is operating in conditions of increased global, national and sectoral risks.

So, important instrument for assessing the financial stability of some company is the financial analysis, through which you can objectively assess the internal and external relations of the analyzed object: to describe its solvency, efficiency and profitability of the activity, prospects for development, and then on its results to make grounded business decisions. The concept of financial stability is complex and multifactorial, it is conditioned by the economic environment of the enterprise, the results of its functioning, the ability to adequately respond to predictable and force majeure changes in internal and external factors [11].

Therefore, financial analysis, like any other complex process, must have its own technology - a sequence of steps aimed at identifying the causes of the deterioration of the organization and the tools for its optimization.

In this case, it is necessary to additionally note, that each economic entity (for example - LC) has its own point of view and purpose in conducting an analysis of the financial condition. Therefore, a special role in this issue is given to the management and shareholders of the enterprise, which iteratively apply the results of financial analysis in substantiating plans, making managerial decisions, developing economic strategies for the medium and long term prospects.

The situation is complicated by the fact that many methods of comparative analysis of the financial situation, applied in the stable western countries, are aimed at more transparent and stable market conditions [12].

The entire spectrum of existing methods of financial analysis (bankruptcy forecasting) can be divided into five groups (as the complexity and power of the economic and mathematical component grows): transformational, qualitative, coefficient, integral and intellectual methods.

All of the above-mentioned methods of assessing the financial sustainability of an enterprise have different disadvantages and advantages, limitations and exceptions, levels of detail and accuracy.

So, considering:

- the results of the analysis and adaptation of FA methods;

- scheme of the developed by authors complex cross-cutting methodology of crisis reengineering of LC [10];

- taking into account the globalized, regional, sectoral specific of LC management;

- given the importance of the dynamic shift (may be caused by fresh forecasting results using a new data) such option as targeted discrete shareholders' / owners' strategic decision for LC crisis program (bankruptcy of the forwarding company; official liquidation of the company; effective sale of the company to new owners; legal withdrawal of liquid assets and formal sale / re-registration of the company; improvement and reorganization of the company in order to continue the further work without its re-engineering etc);

- given the specifics of emerging markets in pre-crisis conditions;

- considering the relevance of Big Data and the prospects for Data Mining in the transport industry [13];

an important and urgent task is the development of a step-by-step iterative integrated methodology of financial analysis and forecasting the bankruptcy of a logistics company, applicable at all stages of the LC life cycle and all phases of a possible crisis.

Analysis of recent research and publications. The research of anti-crisis management is sufficiently substantiated in the works of Voroninoy O.S., Voennoy K.I., Gavrilenko T.V., Kovalchuk N.O., Kravchuk L.S., Pavlyuk A.O., Pryadun YE. A., Fuchedzhy V.I., however, the issue of effective selection, adaptation and scenario use of FA models in the framework of the diagnostic stage before the formation of a comprehensive anti-crisis strategy (for LC, in particular) has not been solved.

It should also be noted the results of the research of Zhdanov V. Yu., Lyubushin N.P., Petrov A.N., Sviridova N.V., Fedorov S.A., Chaksha $\mathrm{V}$. Yu. on the analysis of the effectiveness of certain individual FA methods and bankruptcy forecasting models, which, however, was conducted without taking into account features of crisis management stages and the sector specifics of the transport industry. 
The main part. Below are the results of critical analysis of the major techniques of the FA with the purpose of further generation of a new iterative multi-stage script methodology of the FA of LC, which will take into account the industry and crisis features in emerging markets.

The first group of the methods of financial anal$y$ sis is a simple, transformational methods, aimed at preliminary familiarization with financial reporting and its transformation into more convenient for interpretation and for further in-depth analysis (including intelligent methods of exploratory analysis and machine learning models [14]). But the information obtained during the transformation methods gives a general idea of the financial condition of the enterprise, but it is clearly not enough to make strategic managerial decisions [15].

The above-mentioned reporting transformation procedures using official inflation indices, official exchange rates of foreign currencies and other public indicators serve, first of all, to ensure comparability of the data of different accounting periods, various organizational and functional subjects of analysis.

However, a number of factors limits their effectiveness:

- the movement of funds, as a rule, occurs unevenly during the financial year of the company;

- real rates of inflation usually differ significantly in different asset categories and even for different types of assets in a group;

- official exchange rates and cross-rates in the context of a sharp macroeconomic crisis in Ukraine are not always adequate and timely;

- the valuation of assets, as practice shows, is often quite subjective, despite the regulatory acts adopted by the Ministry of Justice;

- the classic methods of transformation analysis do not take into account the dynamic risks of economic activity in the industry and/or a region, as the practice of recent years has shown.

Thus, the group of transformation methods of FA is descriptive and can not be considered as the basic tool for assessing the financial condition of the LC on emerging markets, but only as a preliminary, reconnaissance, pilot rapid analysis (especially in pre-crisis conditions).

The second group of methods of FA are qualitative methods of assessing the financial condition, which are subdivided into the method of vertical, horizontal analysis, factor analysis, analysis of liquidity balance, SWOT analysis, etc.

However, exclusively through vertical analysis, unambiguous and detailed interpretation of the structure of official financial reporting in order to obtain a forecast of possible bankruptcy is virtually incorrect. In particular, it is ineffective to analyze the structure of an enterprise's funds in relation to some single and universal standard is ineffective on emerging markets, because the specificity of the activities and management of a company (even within a single industry with a difference in technological processes) inevitably has an impact on the structure of assets and liabilities, as there are significant fluctuations in the financial reporting can be caused by a subjective management style and / or a tendency to risky operations by management / shareholders.

The horizontal analysis is not enough to be a universal tool for forecasting bankruptcy of the company due to the following reasons:

- the changes that have taken place characterize the actions of past periods, and there are no reasons to believe that such tendencies persist in the future;

- not having additional data of analytical accounting, subaccounts, it is impossible to uniquely interpret the changes considered (absolute and relative);

- some resulting indicators of financial reporting are due to such a significant number of factors, including external, both economic and political, that it is virtually impossible to predict them based on the analysis of the previous dynamics;

- to estimate the dynamics of the company's performance according to the official financial reporting in Ukrainian conditions - in fact it is impossible;

- some indicators are ineffectively compared because of inflationary effects and due to the possible presence of negative balance sheet items and/or a report about incomes and losses.

Consequently, the main disadvantages of a horizontal analysis actually increase in the trend analysis.

The analysis of liquidity of the balance sheet as a method of financial forecasting according to the data of public official financial reporting in emerging markets leads to not fully adequate results, as the actual maturities of liabilities and a real liquidity of assets can vary considerably even within one balance sheet.

Another one of the tools of financial analysis is the calculation of cash flow, however, as a rule, data is entered in the form by financiers based on experience and lacking clear formalization, in particular, they often form three variants of such a forecast (pessimistic, weighed and optimistic forecasts).

Another very powerful tool that can be used in a financial analysis is a factor analysis. However, this kind of analysis has significant methodological limitations for use in forecasting bankruptcy. This is explained by the fact that in addition to simple and direct causal relationships, in the economy, as a rule, relations between economic phenomena are 
much more complicated, have reciprocal character, lag time and cumulative effect.

One of the main shortcomings of the SWOT analysis lies in its subjective assessments and severe formalization in quantitative terms.

Consequently, we can conclude that the capabilities of the above-mentioned qualitative methods are significantly limited on emerging markets, i.e. in significant and unpredictable inflation, a significant impact on the economic environment of external macro-factors of instability, the possibility of «insider» influences, the presence of «shadow» component of economic activity of business entities.

The coefficient analysis is the third group of methods of the $F A$, and at present, is one of the most commonly used in the financial and analytical practice of instruments for assessing the financial condition on stable markets.

It should be noted that most of the actual coefficient techniques of the FA suggest certain elements of qualitative analysis, that is, most of the popular multi-stage coefficient methods of the FA provide for the hybrid use of both coefficients and attracting qualitative approaches to the FA (especially at the initial stages of the analysis) [16].

So, summing up the above results, analyzing various methods of coefficient analysis of financial stability using relative indicators, it can be argued that almost all of them have drawbacks:

- uncertainty/ambiguity of the limit values of many coefficients (For example, there are no clear and universal substantiated ratios of the ratio of borrowed funds and own funds, since national and sector specificity must be taken into account. In those areas where capital is slowly rotated and a high proportion of non-current assets (construction), the financial leverage ratio can not be high, but in other sectors (transport), where the turnover of a capital is high and the share of fixed capital is relatively low, this coefficient can be much higher);

- existing coefficient methods used to assess the financial condition of enterprises, on the one hand, cover not all aspects of the business entity (see comparative table of coefficient methods); on the other hand, some methods practically do not differ and duplicate each other;

- the multiplicity of existing sets of coefficients and the practical absence of objective and formalized mechanisms for interpreting the values of indicators, hence the subjectivity of obtaining final conclusions and recommendations.

The above-mentioned peculiarities of the application of relative indicators in FA determine their effectiveness in developed markets in stable and competitive macroeconomic conditions.

The next group of FA methods are integrated techniques for assessing financial condition, they involve synthesizing financial indicators into com- plex constructions in the following areas: summary rating (scoring) models, construction of multiple discriminant analysis models (MDA-models) and models based on logistic regression (logit-models). The main purpose of these models is to calculate the integral index on which to generate a forecast based on the measurement of different financial ratios of the enterprise.

It should be noted that currently are used rating systems for assessing the financial condition of an enterprise of two types [17].

The first type involves the classification of enterprises into several groups, the boundaries of which are set in advance by analysts and experts. To apply this methodology, it is sufficient to have financial statements from one company. This type of methodology can be attributed to the methods of Durant, Beaver, Dontsova, Nikiforova, Argenti method (A-score).

The second type of enterprise rating methodology is based on a comparison of financial ratios with a benchmark company. The role of the benchmark is played by the firm, which has the best results from the entire sample of surveyed enterprises. These include the methods of Kukunina I.G., Sheremeta A.D.

So, let's summarize the main disadvantages of rating methods:

1. Any of the indicators of one of the analyzed enterprises (for example, due to insider transactions, unfair competition or unreliable reporting) may be by orders of magnitude higher than that of a large sample of conditional reference values, which complicates comparative analysis and leads to cumulative error in further.

2. Most often the consumer of FA information is interested in liquidity, solvency, profitability or turnover of the enterprise. The rating does not specifically identify this, but gives only an overall estimation, that is, the place of the company in the general list. The rating may offset specific features of the activity of the enterprise under consideration.

Let's analyze a group of methods related to a mathematical and a statistical analysis, they are divided into two directions:

- models based on Multiple-discriminant analysis (MDA) [18];

- models based on logistic regression analysis (logit- models) [19];

- models based on regression of Gaussian analysis (probit models).

Let's analyze the most popular subset of mathematical and statistical methods - MDA models. Despite the prevalence of such bankruptcy of forecasting models (mainly in the stable Western markets and in the academic community), the effectiveness of their use by LC in the emerging markets is quite doubtful due to the following factors: 
1) the experience of applying different MDA models on the same data set produces conflicting results;

2) classic MDA models do not take into account domestic macroeconomic and industry specificity (industry specificity significantly affects the structure of the company balance sheet), and even more the impact of the crisis;

3) parameters of classical published MDAmodels are formed on outdated statistics of stable markets national economies (at least the current global trends and threats and the specificities of emerging markets was not taken into account then calculating them);

4) the existing western classical methods of integrated indicators do not take into account the possible domestic business practice of doing business on emerging markets (presence of "shadow" part of income, "creative" audit in the preparation of official statements, tax optimization within the holdings, etc.);

5) existing models do not involve data usage for more than one year (change in performance over several years is not taken into account at all);

6) given the overwhelming attention of most classic MDA models to liquidity ratios while also considering the possible global and domestic crisises, when interpreting the simulation results, one must understand that the organization may be insolvent at the moment, but this does not mean its real bankruptcy, and even vice versa.

Given the above difficulties in the use of MDA models for forecasting LC bankruptcy, there has been a recent decline in the use of MDA models in the business of bankruptcy risk assessment on emerging markets, with increasing emphasis on Logit and Probit models [20; 21].

In order to predict bankruptcy, it is advisable to use Logit-analysis, since it has the following advantages compared to MDA:

- one of the prerequisites for effective use of the discriminant model is that the discriminant variables in each group obey the multidimensional normal distribution law, that is, the linearly independent variables are a sample of the multidimensional normal distribution. However, emerging markets practice has shown that most often, (especially for scheme companies, companies that intentionally going bankrupt, or objectively crisis transport companies) the condition of subordinate discriminatory variables to the multidimensional normal distribution law is not respected, but logistic regression does not put forward special requirements for the normal distribution of arguments;

- in MDA models, there are often so-called zones of uncertainty, when entering into which the calculated rating indicator can not be made a clear conclusion about the probability of bankruptcy. There are no such zones in Logit-models;

- Logit analysis formalizes nonlinear dependencies, unlike discriminant bankruptcy forecasting models, which pay attention only to the linear dependence of the probability of bankruptcy on some factors;

- Logit analysis uniquely interprets the resulting bankruptcy probability as opposed to discriminatory models that can only give a qualitative degree to that probability.

However, the disadvantages of such models should also be considered:

- it is assumed that the independent input variables do not contain errors or fraud (which is quite possible in emerging markets in unstable pre-crisis conditions);

- models with too little complexity may be inaccurate, and models with excessive complexity may be retrained;

- Logistic regression does not rely on distributional assumptions in the same sense as discriminant analysis. However, your decision may be more stable if the distribution of predictors is multidimensional normal.

- collinearity of predictors can lead to biased estimates and large root mean square errors;

- there are no possibilities for a full-fledged modeling of nonlinear dependencies in logistic regression.

As a conclusion on the advantages of la ogistic regression models, it can be noted that logistic regression is applicable to a wider range of situations than discriminant analysis.

The last group of FA techniques involves intelligent methods of assessing / predicting a financial status that involve the use of machine learning technologies (artificial neural networks [22], regression trees etc) to build quantitative models for assessing financial status.

Such trained models (Al-models) allow not only to detect and take into account hidden patterns using DM technologies, but also could detect anomalies in the LC data and operate in a fraud detection mode.

Such financial models are built with the use of intellectual technologies, effectively work with fuzzy, incomplete, noisy and inaccurate data, that is especially true in crisis times [23].

However, the construction (training) of such models is complicated by the need to collect and use for machine learning of as large as possible sample of a representative, actual and reliable training data set on the full operational activity of the LC, in emerging logistic market on all of the crisis phases.

In view of the above, the authors have developed the complex iterative script technique of 
FA, which includes the following parameters: FA stage order number, Recommended scripting approach to results aggregation and their interpretation, Input information for FA, The proposed method / model of FA, The results of the stage of FA, Alternatives to management decisions (bankruptcy of the LC; official liquidation of the LC; effective sale of the LC to new owners; legal withdrawal of liquid assets and formal sale/re-registration of the LC; improvement and reorganization of the LC in order to continue the further work without its re-engineering). Conceptually, it is outlined in the table 1.

Main conclusions. Therefore, in view of the above, compleated detailed analysis of the practice of FA allowed to identify the following systemic methodological problems for LC in emerging markets:

- in practice, the analysis is reduced to calculations of the relative change in the structural elements of the financial reporting, changes in individual financial ratios; in addition, the time horizon of the study is limited, as a rule, by one or two periods, that is, there is a finding of short-term or tactical tendencies;

- the results of assessing the stability of the LC are based in some cases on insufficiently complete and reliable information (for example, due to optimization of the tax base, there is a tendency for different ways of calculating the tax base, in addition, differences in accounting policies and/or differences in corporate standards of consolidation of reporting etc);

- in most existing and used methods of FA for LC a clear delineation of the analysis of solvency and liquidity is not provided, moreover, almost all attention is focused solely on the assessment of solvency, financial soundness and liquidity;

- in existing models, performance standards and / or weights are calculated on too outdated samples, in addition, which do not take into account either national, sectoral or crisis features in emerging markets;

- detailed analysis of LC's activity has led to the development, calculation and use of a clearly excessive number of indicators, especially since some of them are directly functionally interdependent (for example, the coefficient of autonomy and the ratio of debt to equity);

- comparative analysis of the activity of LC in emerging markets is complicated by the lack of a sectoral reference and a regulatory framework by types of an economic activity and available reliable market indicators (in stable western markets, industry rating agencies produce and regularly publish objective ratings and indicators);

- the internal and external reporting of the LC in emerging markets is often distorted through the inflation processes, insider or monopoly influence, which mainly affect the horizontal analysis, not the results of the vertical analysis.

Summarizing the comprehensive analysis of existing and used methods of FA for LC, and given the author's practical industry experience, it can be confidently stated that no existing algorithm of FA can not give an adequate forecast of the financial status of LC applicable at all stages of the LC life cycle and all phases of a possible crisis in emerging markets.

Thus, a reliable, relevant, and dynamic forecast of the loss of financial stability (bankruptcy risk) of a LC in emerging markets is possible when the following, quite difficult for practical implementation, conditions are fulfilled:

1) the data set for training forecast model should include date for the longest possible time period of the LC's activity (taking into account possible mergers and acquisitions of LC, actual or formal scheme re-registrations of legal entities of $L C$ );

2) the data used to the training forecast models should accurately reflect the real state of the LC, i.e. not only contain data from official reporting forms, but also include all possible internal reporting; taking into account possible changes in the standards of bookeeping official and internal reporting of the $\mathrm{LC}$; taking into account possible tax optimization and transfer price optimization schemes as part of the official or non-official holding corporation;

3) should be taken into account when constructing effective models of predicting bankruptcy risk of LC in emerging markets not only solvency and financial sustainability indicators, but also business activity and efficiency indicators of LC's operating profile, credit (leasing) history, marketing indicators, quality and filling «strategic clients portfolio" of LC etc.;

4) additionally, regarding crisis and pre-crisis conditions of LC in emerging markets it is necessary to use in the forecasting model some macro indicators in macroeconomics, sectoral domestic policy and / or foreign policy and security, which will often be categorical and expertly assessed (for example, describing risks through regional conflicts, trade wars, epidemics etc.);

5) the classified sample for training of the forecast model, should be verified to the possibility of scheme of hidden bankruptcies or bankruptcies through re-registration of LC;

6 ) in order to achieve higher accuracy of the results of such forecast models, it is necessary to systematically (at least once a financial year) critically review the set of indicators and recalibrate the coefficients of their weighting influence correspondence with dynamic targeting of the strategic goals of the shareholders of LC. 


\begin{tabular}{|c|c|c|c|c|c|c|c|}
\hline $\begin{array}{l}0 \\
\frac{0}{0} \\
\frac{3}{2}\end{array}$ & 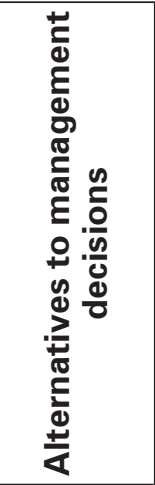 & 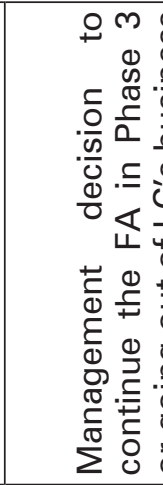 & 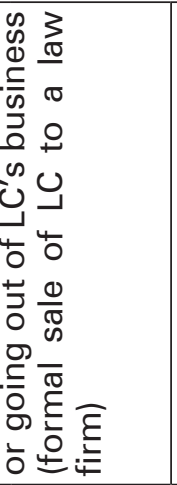 & 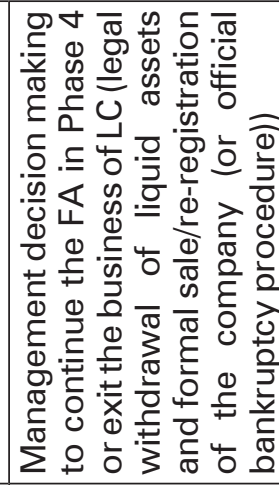 & 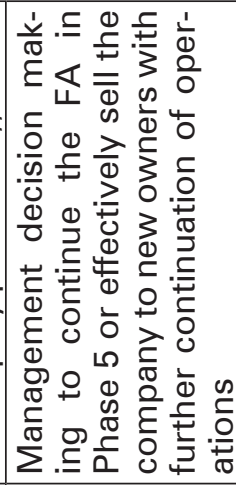 & 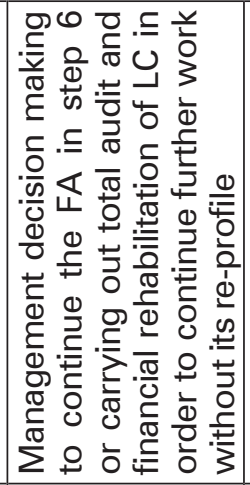 & 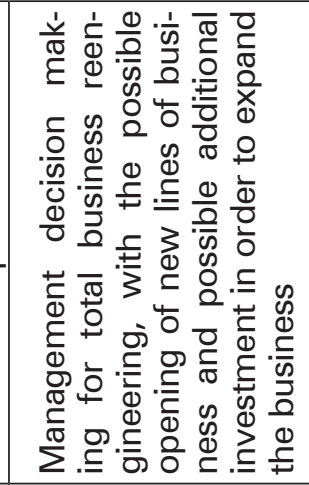 \\
\hline 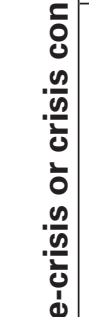 & 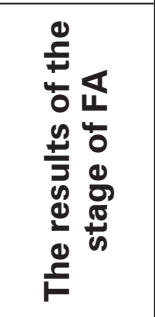 & 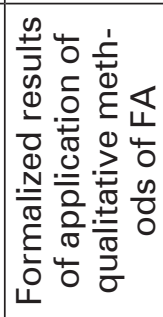 & 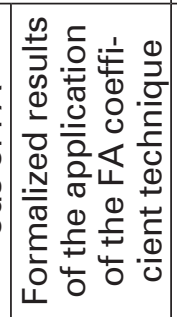 & 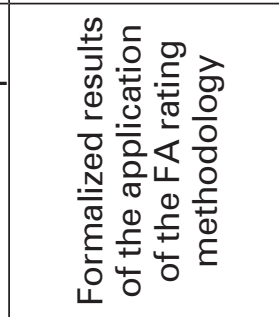 & 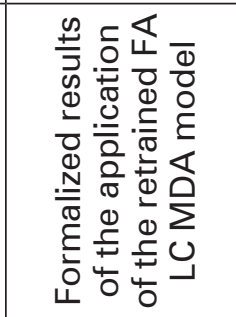 & 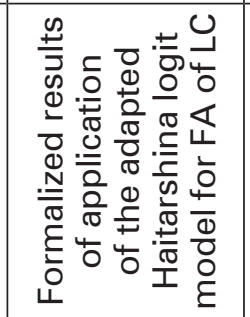 & 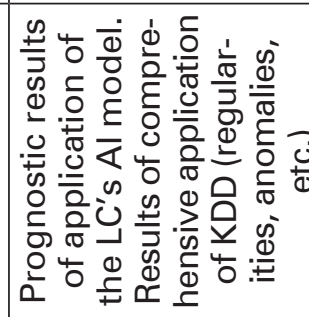 \\
\hline 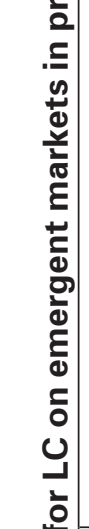 & 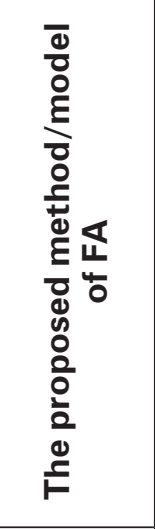 & 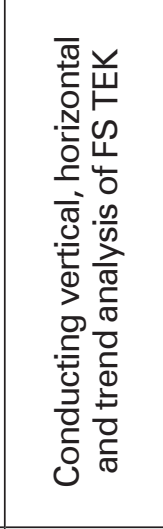 & 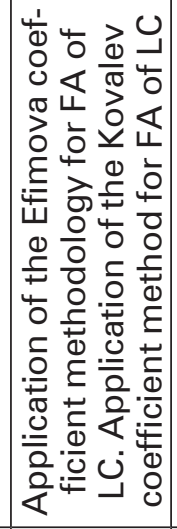 & 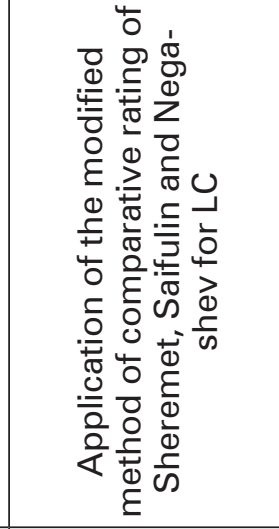 & 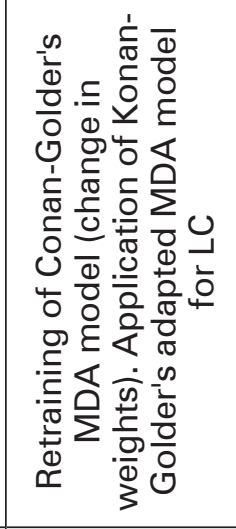 & 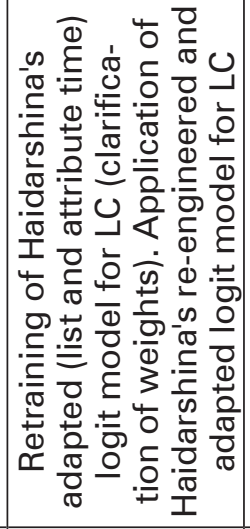 & 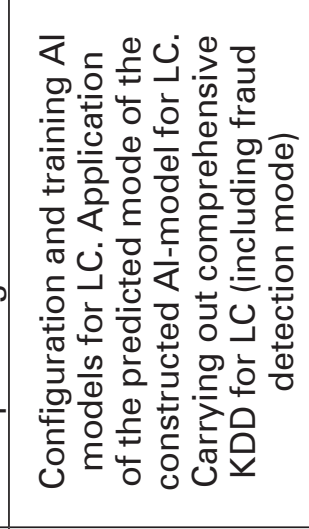 \\
\hline 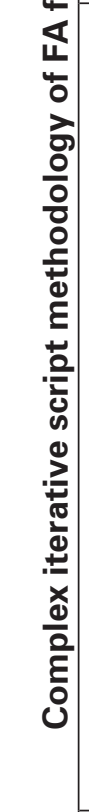 & 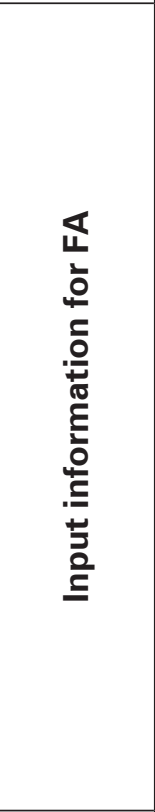 & 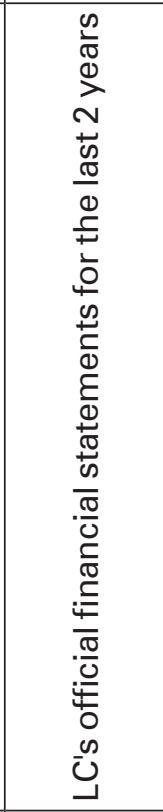 & 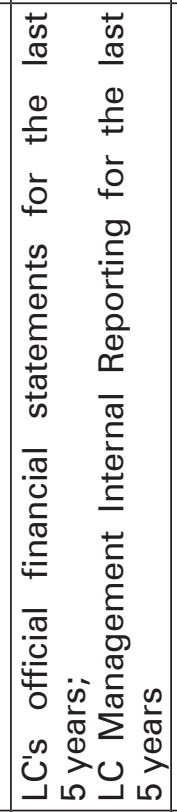 & 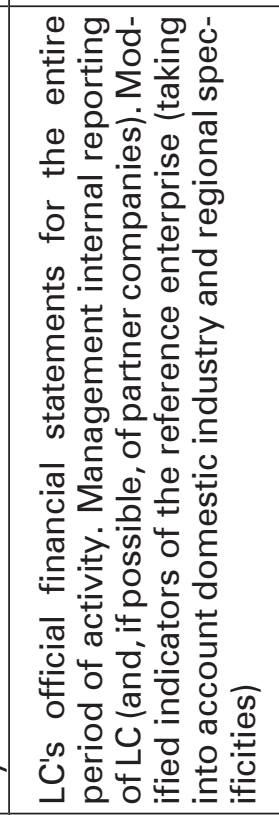 & 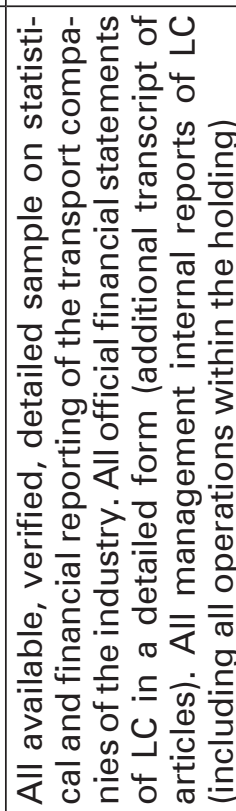 & 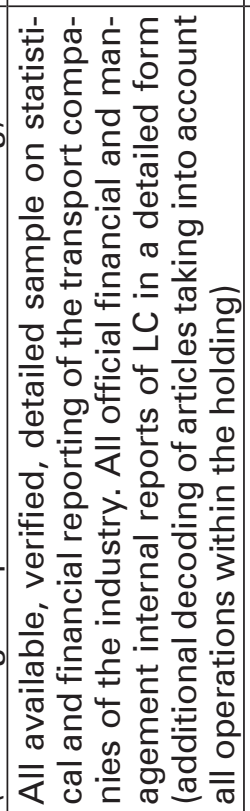 & 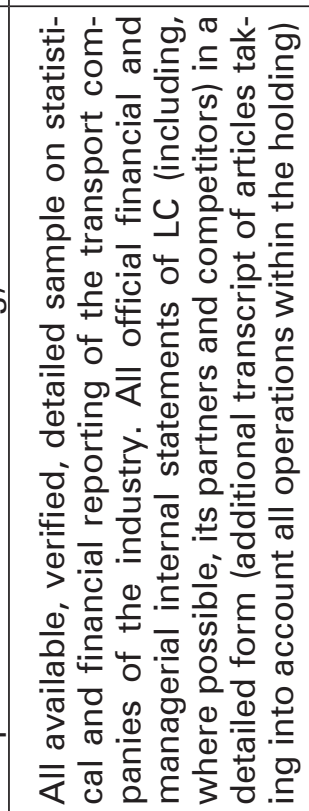 \\
\hline & 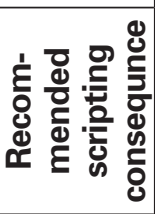 & 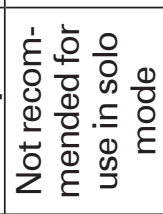 & \pm & $\stackrel{m}{\stackrel{m}{\sim}}$ & $\nabla$ & $\begin{array}{l}\stackrel{\log }{+} \\
+\end{array}$ & $\begin{array}{l}0 \\
+ \\
\llcorner\end{array}$ \\
\hline & $\begin{array}{c}\text { \# גәрдо } \\
\text { әбеұS }\end{array}$ & ${ }^{\circ}$ & i & mं & $\dot{\sigma}$ & $\nu^{\circ}$ & $0^{\circ}$ \\
\hline
\end{tabular}


Prospects of the results of the research use. In this article, the important and urgent task is solved: the development of a step-by-step iterative integrated methodology of financial analysis and forecasting the bankruptcy of a logistics company, applicable at all stages of the LC life cycle and all phases of a possible crisis is developed.

The results obtained in the article can be used not only by LC in emerging markets but alsow by other type of business in crisis and pre-crisis conditions in emerging or even in stable markets.

\section{References:}

1. IMF warns world growth slowest since financial crisis (2019) // $B B C$ News. Available at: https://www.bbc.com/news/business-50047929 (Accessed 04 February 2020).

2. Gita Gopinath. (2019) The World Economy: Synchronized Slowdown, Precarious Outlook. Available at: https://blogs.imf.org/2019/10/15/the-world-economy-synchronized-slowdown-precariousoutlook/ (Accessed 02 February 2020).

3. Krasnyuk Maxim and Kustarovskiy Oleksandr. (2017) "The development of the concept and set of practical measures of anti-crisis logistics management in the current Ukraine conditions" // Management theory \& practice. Publisher: Warsaw Management University. № 19(1), pp. 31-38.

4. Melinda Haring. (2019) Q\&A: Will Ukraine Face a Serious Financial Crisis If It Doesn't Get IMF Money Before November? // Atlantic Council. Available at: https://www.atlanticcouncil.org/blogs/ ukrainealert/q-a-will-ukraine-face-a-serious-financial-crisis-if-it-doesn-t-get-imf-money-beforenovember/ (Accessed 01 February 2020).

5. Matilda Sevon. (2019) The Ukrainian economy: the way forward after a year of political turbulence. // Bruegel. Available at: https://bruegel.org/events/the-ukrainian-economy-the-way-forward-after-ayear-of-political-turbulence/ (Accessed 06 February 2020).

6. Global Manufacturing Downturn, Rising Trade Barriers (2019) // World Economic Outlook. Available at: https://www.imf.org/en/Publications/WEO/Issues/2019/10/01/world-economic-outlookoctober-2019 (Accessed 01 February 2020).

7. Maeva Cousin. (2020) How the Coronavirus Can Infect Global Supply Chains. // Bloomberg. Available at: https://www.bloomberg.com/news/articles/2020-01-31/how-the-coronavirus-can-infectglobal-supply-chains-map?srnd=premium-europe (Accessed 01 February 2020).

8. Sandrine Amiel. (2020) ECB's Lagarde warns coronavirus is fueling economic uncertainty. // Euronews. Available at: https://www.euronews.com/2020/02/05/ecb-s-lagarde-warns-coronavirusis-fueling-economic-uncertainty (Accessed 03 February 2020).

9. Dimitrios Folinas, Naoum Tsolakis and Dimitrios Aidonis (2018) "Logistics Services Sector and Economic Recession in Greece: Challenges and Opportunities", DOI: 10.3390/logistics2030016.

10. Krasnyuk, M., Hrashchenko, I., Krasniuk, S. \& Kustarovskiy, O. (2019). Reengineering of a Logistic Company and its Information System Taking into Account Macroeconomic Crisis. Modern Economics, 13(2019), 141-153. DOI: https://doi.org/10.31521/modecon.V13(2019)-23.

11. Lyubushin N.P., Babicheva N.E., Galushkina A.I., Kozlova L.V. (2010) Analiz metodov imodelej oczenki finansovoj ustojchivosti organizaczij. [Analysis of methods and models for assessing the financial stability of organizations]. Available at: https://cyberleninka.ru/article/n/analiz-metodov-i-modeley-otsenki-finansovoy-ustoychivosti-organizatsiy (Accessed 01 February 2020). [in Russian]

12. Kustrich L.A. (2014) Primenenie metodicheskikh podkhodov oczenki finansovoj ustojchivosti predpriyatiya kak e tap proczessa upravleniya eyu. [Application of methodological approaches to assessing the financial stability of an enterprise as a stage in the process of managing it.]. Available at: http://sovman.ru/article/4705/ (Accessed 02 February 2020). [in Russian]

13. Krasnyuk, M.T., Hrashchenko, I.S., Kustarovskiy, O.D. and Krasniuk, S.O. (2018) Methodology of effective application of Big Data and Data Mining technologies as an important anti-crisis component of the complex policy of logistic business optimization // Economies' Horizons, No. 3(6), pp. 121-136, doi: https://doi.org/10.31499/2616-5236.3(6).2018.156317.

14. Krasnyuk M.T. and Kustarovskiy O.D. (2017) Problemy ta perspektyvy rozvytku ukrainskykh lohistychno-informatsiinykh system v umovakh hlobalizovanoi ekonomiky ta makroekonomichnykh kryzovykh yavyshch [The problems are the prospect of developing Ukrainian logistical and informational systems in the global economy and the macroeconomic crises of emergencies] Investytsii: praktyka ta dosvid. - Kyiv. - May 2017. - № 10. - S. 34-39. [in Ukrainian]

15. Novopashina E.A. (2008) Praktika oczenki finansovogo sostoyaniya khozyajstvuyushhego sub `ekta s uchetom mirovogo opy 'ta [The practice of assessing the financial condition of an economic entity taking into account international experience] Available at: https://cyberleninka.ru/article/n/metodika-otsenki-finansovogo-sostoyaniya-predpriyatiya-opredelenie-krizisnoy-i-izbytochnoy-likvidnosti (Accessed 01 February 2020). [in Russian]

16. Chaksh V.Yu. (2014) Cravnitel 'naya kharakteristika metodik analiza finansovogo sostoyaniya. [Comparative characteristic of financial condition analysis techniques] Available at: http://elib.sfu-kras.ru/ handle/2311/19016 (Accessed 04 February 2020). [in Russian] 
17. Sviridova N.V. (1998) Sravnitel ’ny `j analiz finansovogo sostoyaniya predpriyatij. [Comparative analysis of the financial condition of enterprises] Available at: http://www.dissercat.com/content/sravnitelnyi-analiz-finansovogo-sostoyaniya-predpriyatii (Accessed 05 February 2020). [in Russian]

18. Zhdanov V.Yu. (2018) Modeli bankrotstva zarubezhny kh predpriyatij s formulami rascheta (4 MDA-modeli). [Bankruptcy models of foreign enterprises with calculation formulas (4 MDAmodels)] Available at: http://finzz.ru/modeli-bankrotstva-zarubezhnyx-predpriyatij-4-mda-modeli. html (Accessed 01 February 2020). [in Russian]

19. Petrov A.N. (2016) Oczenka riska veroyatnosti bankrotstva s pomoshh `yu logit-modelej. [Bankruptcy risk assessment using logit models.] Available at: https://cyberleninka.ru/article/n/otsenka-riskaveroyatnosti-bankrotstva-na-osnove-logit-modeley(Accessed 01 February 2020). [in Russian]

20. Fyodorova S.A. (2016) Prognozirovanie bankrotstva predpriyatij $v$ transportnoj otrasli. [Forecasting bankruptcy of enterprises in the transport industry] Available at: https://cyberleninka.ru/article/n/ prognozirovanie-bankrotstva-predpriyatiy-na-primere-otrasley-stroitelstva-promyshlennosti-transporta-selskogo-hozyaystva-i-torgovli (Accessed 01 February 2020). [in Russian]

21. Zhdanov V.Yu. (2012) Modeli oczenki veroyatnosti bankrotstva predpriyatij [Models for assessing the probability of bankruptcy of enterprises]. Available at: http://finzz.ru/modeli-ocenki-veroyatnostibankrotstva.html (Accessed 06 February 2020). [in Russian]

22. Wei He (2013) An Inventory Controlled Supply Chain Model Based on Improved BP Neural Network. Available at: https://www.hindawi.com/journals/ddns/2013/537675/ (Accessed 03 February 2020).

23. Krasnyuk M.T., Herashchenko I.S. and Kustarovskiy O.D. (2018) Udoskonalennia ekonomiko-matematychnoho modeliuvannia rezultativ vprovadzhennia okremykh elementiv adaptyvnoi antykryzovoi polityky kompanii transportnoi haluzi Ukrainy [Improvement of the economic and mathematical modeling of the results of implementation of individual elements of the adaptive anti-crisis policy of the transport industry companies of Ukraine] Naukovyi visnyk Uzhhorodskoho universytetu Seriia "Ekonomika". Vypusk 1(51). - Uzhhorod, 2018. - S. 205-211. [in Ukrainian] 